https://doi.org/10.11646/zootaxa.4369.1.6

http://zoobank.org/urn:lsid:zoobank.org:pub:554E4431-B96C-467E-953F-A3244239422E

\title{
Redescription of Austrothelphusa wasselli (Bishop, 1963) (Crustacea: Brachyura: Gecarcinucidae), and designation of a new species from the Gilbert River, north Queensland, Australia
}

\author{
MURTADA D. NASER ${ }^{1,4}$, PETER J. F. DAVIE ${ }^{2} \&$ NATHAN J. WALTHAM ${ }^{3}$

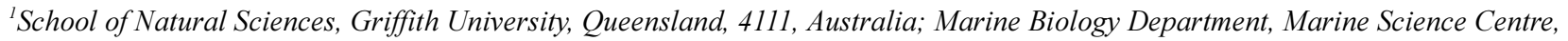 \\ University of Basrah, Basrah, Iraq. \\ ${ }^{2}$ Queensland Museum and Sciencentre, PO Box 3300, South Brisbane, Queensland, 4101, Australia. \\ ${ }^{3}$ Centre for Tropical Water and Aquatic Ecosystem Research (TropWATER), College of Science and Engineering, James Cook Univer- \\ sity, Townsville Campus, Queensland, 4811, Australia. \\ ${ }^{4}$ Corresponding author.E-mail: murtada.naser@griffithuni.edu.au
}

\begin{abstract}
A new species of freshwater crab, Austrothelphusa gilbertensis, is described from Gilbert River Catchment, north-western Queensland. It is morphologically most similar to A. wasselli Bishop, 1963, described from the eastward flowing Stewart Drainage Basin, much further to the north-east on Cape York. It differs from $A$. wasselli by several morphological characters including, better defined gastro-cardiac carapace grooves, cervical groove relatively deeper, postfrontal lobes more prominent and bearing striated crests, larger and fewer spots on carapace and legs, epibranchial tooth more prominent, walking legs more slender, and G1 more strongly curved. A CO1 genetic divergence of greater than $6 \%$ confirms its novel status. Intraspecific $\mathrm{CO} 1$ divergence within catchments is also discussed.
\end{abstract}

Key words: Austrothelphusa, new species, Gilbert River Catchment, Austrothelphusa wasselli, CO1, Cape York, freshwater

\section{Introduction}

DNA analyses using mitochondrial COI and 16s genes have been widely used to support species discrimination, with the barcoding portion of COI being held as particularly useful (Hebert et al. 2003; Hajibabaei et al. 2007), including in Crustacea (Costa et al. 2007; Lefébure et al. 2006; Matzen da Silva et al. 2011). Such use of genetics is especially useful where there are species-complexes with high morphological similarity and limited diagnostic characters (Keenan et al. 1998; Burton \& Davie 2007; Lai et al. 2010; Shy et al. 2014). Such is the case with Austrothelphusa, an Australian indigenous freshwater crab genus that has a wide distribution across northern and inland Australia. Only one species has been reported from outside this region, A. insularis (Colosi, 1919) from Fiji, however as it has not been subsequently found there, its type locality is considered to have been mistaken, and its status remains unclear ( $\mathrm{Ng}$ et al. 2008: 73).

Riek (1951) provided the first review of the Australian freshwater crabs, under the name Paratelphusa (Liotelphusa) Alcock, 1909, the generic/subgeneric combination accepted at that time. This was followed 12 years later by the more thorough revisionary work of Bishop (1963) who recognised six species: Austrothelphusa agassizi (Rathbun, 1905), A. angustifrons (A. Milne Edwards, 1869), A. raceki (Bishop, 1963), A. transversa (von Martens, 1868), A. valentula (Riek, 1951) and A. wasselli (Bishop, 1963). Since then only one further species has been described, A. tigrina Short, 1994 (Davie 2002). Davie \& Gopurenko (2010), however, in discussing their unpublished genetic work, indicated that there are many more species within Austrothelphusa than previously thought, with numerous cryptic species isolated within the many coastal catchments across northern Australia. The present study is part of a larger work currently under way to investigate such cryptic speciation as reflected within a group of putative species related to $A$. wasselli (hereinafter referred to as the $A$. wasselli species-complex or $A$. 
wasselli sensu lato). A diagnosis of the principle characters by which this species-complex can be recognized is presented later under the heading of Taxonomy.

The type locality for $A$. wasselli is in the Stewart River Catchment on eastern Cape York, but the original description noted that it could also be found in the Walsh River, Mitchell Catchment, around $400 \mathrm{kms}$ further south (see further discussion later). Current Australian museum records indicate that " $A$. wasselli" has now been found in numerous localities and river catchments across much of Cape York (Atlas of Living Australia, ala.org.au, accessed July 2017), and thus a more thorough investigation into potential inter-catchment variability, and possible speciation, is worthy of pursuit. In this regard, recent collections in the Queensland Museum from the northwesterly flowing Gilbert River, are clearly similar to A. wasselli, and have been previously identified as such, but differences in several morphological characters made us suspect it could be a novel species. We here present mitochondrial COI genetic sequence data (barcoding region) that provide further support for our supposition that the Gilbert River Catchment samples are a new species within the $A$. wasselli complex. We also further briefly discuss genetic intrapopulation variability, and its implication in helping determine species boundaries within the genus.

The Gilbert River is $610 \mathrm{~km}$ long, and with a catchment covering $46,810 \mathrm{~km}^{2}$ (Fig. 1), it has the sixth-highest discharge of any river in Australia. Its head-waters begin in the western uplands of the Great Dividing Range and it drains to the sea near the port town of Karumba in the southern Gulf of Carpentaria.

All specimens examined are lodged in the collections of the Queensland Museum, Brisbane (QM), and are listed in Table 1. Measurements, in millimeters ( $\mathrm{mm}$ ). Abbreviations: G1, male first gonopod; CW, carapace width; CL, carapace length; P5, fifth pereopod (= fourth ambulatory leg); R., River; s, second.

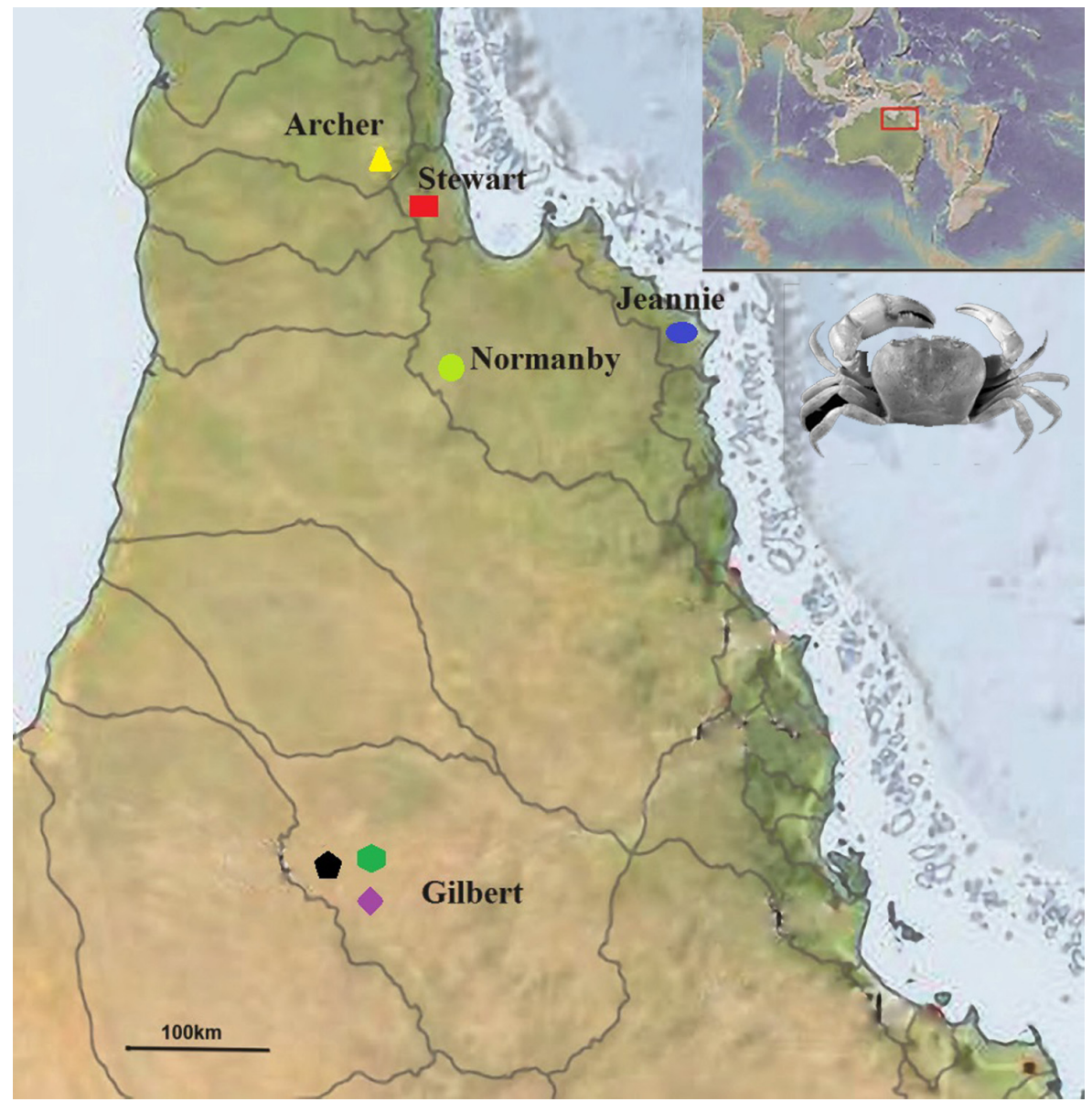

FIGURE 1. Map of Cape York, Queensland showing catchments and localities that were sampled for the present study. In the Gilbert Catchment, black pentagon $=$ Venture Creek, dark green hexagon $=$ small branch of Gilbert River, and purple diamond= Pleasant Creek; in the Normanby Catchment, light green spot= Healy Creek; in the Jeannie catchment, blue oval = Howick River; in the Stewart Catchment, red rectangle = Stewart River; and in the Archer Catchment, yellow triangle $=$ Oscar Creek (see Table 1 for precise localities). The crab shown is the holotype male of Austrothelphusa gilbertensis sp. nov. (refer to Fig. $8)$. 


\section{Genetic methods}

Genomic DNA was isolated from the muscle tissue of ambulatory legs by using the QIAgen DNAeasy kit following the protocol outlined by the manufacturers. A portion of the COI gene was amplified with PCR using the following primers LCO1490 (GGTCAACAAATCATAAAGATATTGG), and HCO2198 (TAAACTTCAGGGTGA CCAAAAAATCA) (Folmer et al. 1994) or COL6b (ACAAATCATAAAGATATYGG), and COH6 (TADACTTCDGGRTGDCCAAARAAYCA) (Schubart \& Huber 2006). PCR mastermixes totaled $12.5 \mu \mathrm{L}$ and consisted of: $1.25 \mu \mathrm{L}$ of $10 \mathrm{x}$ polymerase reaction buffer, $2 \mathrm{mM}$ of $\mathrm{MgCl}_{2}, 0.4 \mu \mathrm{M}$ of forward primers, $0.4 \mu \mathrm{M}$ of reverse primer, $0.2 \mathrm{mM}$ of dNTPs, 0.275 units white Taq polymerase, $0.5 \mu \mathrm{L}$ of template DNA and $7.475 \mu \mathrm{L}$ deionized distilled water. The PCR conditions for the above primers included denaturation for $50 \mathrm{~s}$ at $94^{\circ} \mathrm{C}$, annealing for $70 \mathrm{~s}$ at $45^{\circ} \mathrm{C}$, and extension for $60 \mathrm{~s}$ at $72^{\circ} \mathrm{C}(40 \mathrm{cycles})$, followed by extension for $10 \mathrm{~min}$ at $72^{\circ} \mathrm{C}$. For sequencing, the PCR products were electrophoresed on agarose gel, then dissected and purified by Nucleospin ${ }^{\circledR}$ (Macherey-Nagel). Purified products were subsequently sequenced on ABI automatic capillary sequencer (Macrogene, Inc., Korea) using LCO primers.

Nucleotide sequences were aligned using Clustalw implemented in GENEIOUS 8.0.5 (Kearse et al. 2012), and sequences were checked visually for ambiguous peaks. To ensure that nuclear mitochondrial pseudogenes had not been amplified, the sequences of protein coding gene (COI) were translated into aminoacids to check for indels and stop codons (Song et al. 2008). Estimation of evolutionary divergence between sequences was conducted using the Kimura 2-parameter model (Kimura 1980) in MEGA 7 (Kumar et al. 2016).

The best-fitting model for sequence evolution of the COI dataset was determined by jModelTest 2.1.7 (Darriba et al. 2012), selected under Akaike information criterion (AIC). The obtained best model was HKY $+\mathrm{G}$. A maximum likelihood (ML) tree was constructed using the program MEGA (version 7, Kumar et al. 2016) with 2000 bootstrap replications of a simple heuristic search, while Bayesian analyses were conducted in MrBayes 3.2.4 (Ronquist et al. 2012). Two parallel runs were created. In each run, four MCMC chains (three heated and one cold) were run for 5 million generations and trees sampled every 1000th generation. The first $25 \%$ from the cold chain was discarded as burn-in. The average standard deviation (SD) of split frequencies between both runs was checked. The sampled parameters were investigated using Tracer 1.6 (Rambaut et al. 2014). The maximum clade credibility tree with the nodal posterior probability was generated by TreeAnnotator 1.8.2 (Drummond et al. 2012).

Both Kimura-2-parameter (K2P) and uncorrected pairwise distances were calculated (Table 2). Srivathsan \& Meier (2012) were highly critical of the use of K2P as the "application of nucleotide substitution models will generally yield distances that are larger than those based on uncorrected distances." However, they also stated that when sequences with $<5 \%$ interspecific distances are only used in the analysis "K2P and uncorrected distances yield similar barcoding gaps". They regarded the regular use of K2P distances by the majority of workers as a legacy practice from the early years of barcoding and recommended that henceforth uncorrected pairwise distances should instead become the standard. In deference to this approach we have presented both values here. However, most crab workers have continued to use K2P distance as the preferred measure of intra- and interspecific divergence. So in the interests of making meaningful comparisons with other modern work in this field our discussion relies only on K2P comparisons.

Austrothelphusa raceki (Bishop, 1963) was chosen as an outgroup species because it occurs sympatrically with A. wasselli, but more importantly, unpublished genetic analyses by Davie \& Gopurenko show it (as presently conceived) to form a monophyletic clade more closely related to $A$. wasselli sensu lato than to any other known Australian species.

\section{Results}

A 606-bp fragment of COI was amplified from 8 specimens belonging to the $A$. wasselli species-complex, and including a broad geographic coverage across five different catchments (Table 1). The studied fragment of the COI sequences was AT rich (61.4\%) (T, 34.4\%; A, 27.0\%; G, 15.9\%; C, 22.7\%).

The phylogenetic tree (Fig. 2) clearly shows that the three samples of A. gilbertensis sp. nov. form a wellsupported monophyletic clade (BI:ML: 1/98) distinct from a clade containing $A$. wasselli samples from the Stewart (topotypic), and Archer Catchments (BI:ML: 1/95). The other two samples (one from Normanby Catchment, and 
the other from the Jeannie Catchment) form a separate clade again, though with weaker support (BI:ML: 0.69/59). The integrity and relationships of the three clades presented here are likely to be affected or changed when a larger dataset including more catchments is analysed as part of the bigger study currently being undertaken, and in particular when more genes are utilised.

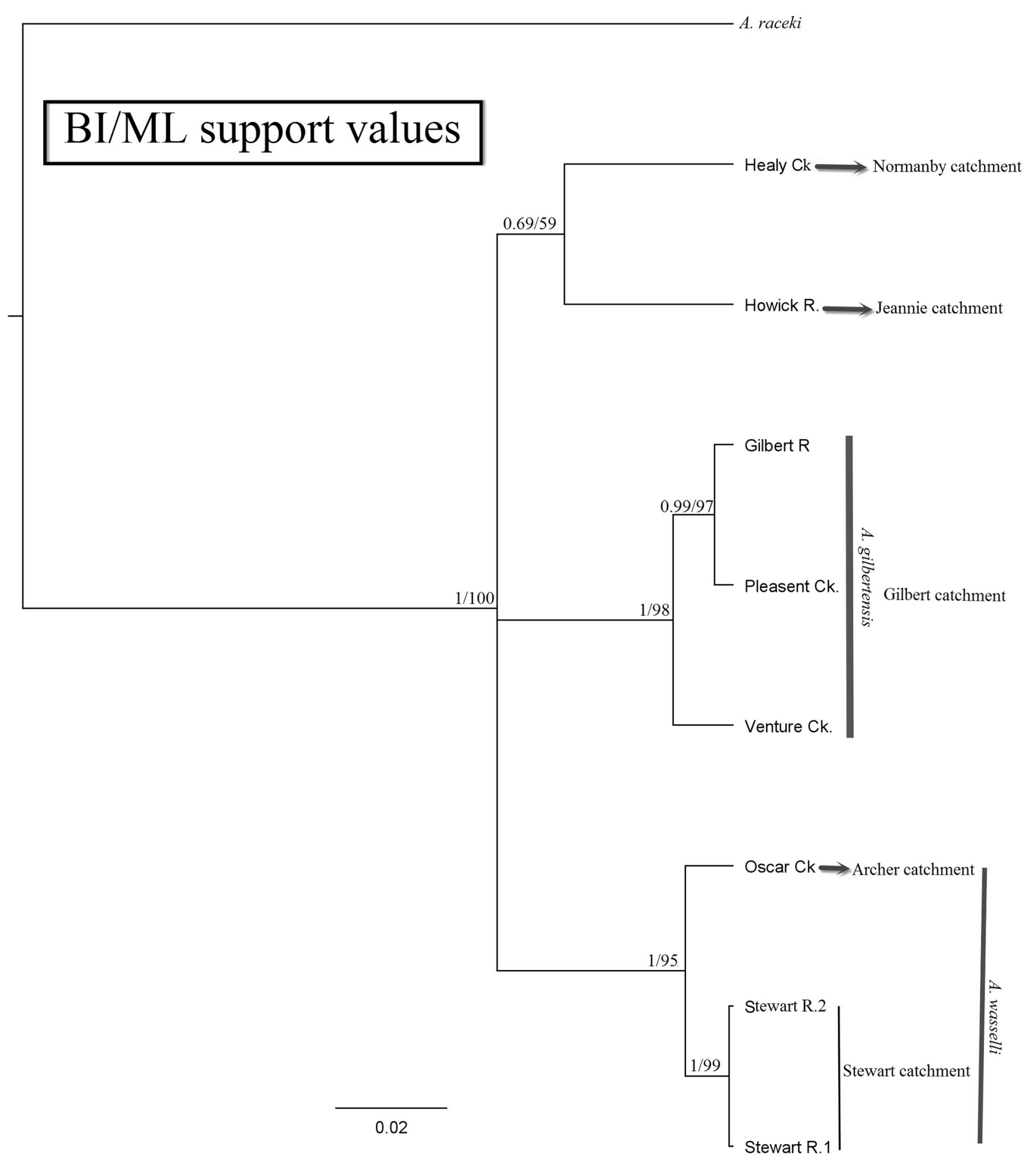

FIGURE 2. Bayesian Inference and Maximum Likelihood tree topology for Austrothelphusa samples included in this study, derived from COI gene mtDNA sequences (606 basepairs). BI and ML statistical values on the nodes indicate posterior probabilities and bootstrap support, respectively (\%).

The COI pairwise nucleotide divergences using both K2P and uncorrected pairwise distances are shown in Table 2 with the latter values slightly less than the former as found by Srivathsan \& Meier (2012). A. gilbertensis 
differs from all other samples by $5-8 \%$, and from the outgroup species, $A$. raceki by $13-14 \%$. In particular, it differs from $A$. wasselli samples by $5.4-6.4 \%$

The three samples of $A$. gilbertensis show a K2P divergence of around $1.8 \%$, despite all three localities being relatively close to each other (Fig. 1). The samples of $A$. wasselli from the adjacent Stewart and Archer Catchments also show a genetic divergence of only $1.4 \%$. On the other hand, specimens from Healy Creek (Normanby Catchment) and Howick River (Jeannie catchment) are strongly separated from each other by at least $6.5 \%$, which is similar to their individual genetic divergences from A. wasselli sensu stricto (5 to $6 \%$ ), and thus is also supportive of each being recognized as separate species within the complex.

TABLE 1. Sampling localities of the Austrothelphusa "wasselli" species complex and the outgroup (A. raceki) used in the genetic analyses, including GeneBank accession details.

\begin{tabular}{|c|c|c|c|c|c|c|}
\hline Taxon - Genus & $\begin{array}{l}\text { Registration } \\
\text { Number }\end{array}$ & Locality Name & Latitude & Longitude & Catchment & $\begin{array}{l}\text { GeneBank } \\
\text { accession } \\
\text { number }\end{array}$ \\
\hline A. wasselli group & QM-W20049 & Stewart R & $14^{\circ} 8^{\prime} \mathrm{S}$ & $143^{\circ} 16^{\prime} 4^{\prime \prime} \mathrm{E}$ & Stewart & MF458172 \\
\hline A. wasselli group & QM-W29187 & $\begin{array}{l}\text { Oscar Creek, } 2.1 \mathrm{~km} \mathrm{SSE} \text { of } \\
\text { Coen, FNQ }\end{array}$ & $13^{\circ} 57^{\prime} 41^{\prime \prime} \mathrm{S}$ & $143^{\circ} 12^{\prime} 34^{\prime \prime} \mathrm{E}$ & Archer & MF458170 \\
\hline A. wasselli group & QM-W20055 & Howick R & $14^{\circ} 36^{\prime} 4^{\prime \prime} \mathrm{S}$ & $144^{\circ} 41^{\prime} 8^{\prime \prime} \mathrm{E}$ & Jeannie & MF458169 \\
\hline A. wasselli group & QM-W52132 & $\begin{array}{l}\text { Healy Creek Crossing, } \\
\text { Peninsula Developmental Rd, } \\
\text { Lakefield NP }\end{array}$ & $15^{\circ} 8^{\prime} 5.208^{\prime \prime} \mathrm{S}$ & $143^{\circ} 48^{\prime} 2.448^{\prime \prime} \mathrm{E}$ & Normanby & MF458168 \\
\hline A. wasselli group & QM-W28040 & Venture Creek, E of Croydon & $18^{\circ} 7^{\prime} \mathrm{S}$ & $142^{\circ} 43^{\prime} \mathrm{E}$ & Gilbert & MF458173 \\
\hline A. wasselli group & QM-W28305 & Pleasant Creek & $18^{\circ} 12^{\prime} 6.8^{\prime \prime} \mathrm{S}$ & $142^{\circ} 52^{\prime} 19.3^{\prime \prime} \mathrm{E}$ & Gilbert & MF458171 \\
\hline A. wasselli group & QM-W28339 & Creek off Gilbert River & $18^{\circ} 9^{\prime} 15.60^{\prime \prime} \mathrm{S}$ & $142^{\circ} 52^{\prime} 10.70^{\prime \prime} \mathrm{E}$ & Gilbert & MF458167 \\
\hline A. raceki & QM-W52284 & $\begin{array}{l}\text { Pennefather Rd, Tea Tree } \\
\text { Swamp, Andoom, nr Weipa }\end{array}$ & $12^{\circ} 29^{\prime} 33.252^{\prime \prime} \mathrm{S}$ & $141^{\circ} 56^{\prime} 36.564^{\prime \prime} \mathrm{E}$ & Embley & MF458166 \\
\hline
\end{tabular}

TABLE 2. K2P and uncorrected pairwise distances (within [ ]) for the Col gene between samples of the A.wasselli species-complex (see Table 1). Rows 1-3 represent A. gilbertensis sp. nov., described here. Samples from Healy Creek and from Howick River, also appear to represent new species, and are being studied as part of a broader revision of the species-complex.

\begin{tabular}{|c|c|c|c|c|c|c|c|c|c|c|}
\hline & Species & Locality & 1 & 2 & 3 & 4 & 5 & 6 & 7 & 8 \\
\hline 1 & A. gilbertensis & Gilbert R. & & & & & & & & \\
\hline 2 & A. gilbertensis & Pleasant Ck & 0.007 & & & & & & & \\
\hline 3 & A. gilbertensis & Venture Ck & $\begin{array}{l}0.018 \\
{[0.017]}\end{array}$ & $\begin{array}{l}0.018 \\
{[0.017]}\end{array}$ & & & & & & \\
\hline 4 & A. wasselli & Oscar Ck. & $\begin{array}{l}0.064 \\
{[0.060]}\end{array}$ & $\begin{array}{l}0.060 \\
{[0.057]}\end{array}$ & $\begin{array}{l}0.055 \\
{[0.052]}\end{array}$ & & & & & \\
\hline 5 & A. wasselli & Stewart R. 2 & $\begin{array}{l}0.064 \\
{[0.060]}\end{array}$ & $\begin{array}{l}0.060 \\
{[0.057]}\end{array}$ & $\begin{array}{l}0.054 \\
{[0.052]}\end{array}$ & $\begin{array}{l}0.014 \\
{[0.014]}\end{array}$ & & & & \\
\hline 6 & A. wasselli & Stewart R. 1 & $\begin{array}{l}0.064 \\
{[0.060]}\end{array}$ & $\begin{array}{l}0.060 \\
{[0.057]}\end{array}$ & $\begin{array}{l}0.054 \\
{[0.052]}\end{array}$ & $\begin{array}{l}0.014 \\
{[0.014]}\end{array}$ & $\begin{array}{l}0.0 \\
{[0.0]}\end{array}$ & & & \\
\hline 7 & A. c.f. wasselli sp.1 & Healy Ck & $\begin{array}{l}0.081 \\
{[0.074]}\end{array}$ & $\begin{array}{l}0.081 \\
{[0.074]}\end{array}$ & $\begin{array}{l}0.067 \\
{[0.062]}\end{array}$ & $\begin{array}{l}0.058 \\
{[0.055]}\end{array}$ & $\begin{array}{l}0.055 \\
{[0.052]}\end{array}$ & $\begin{array}{l}0.055 \\
{[0.052]}\end{array}$ & & \\
\hline 8 & A. c.f. wasselli sp. 2 & Howick R. & $\begin{array}{l}0.075 \\
{[0.069]}\end{array}$ & $\begin{array}{l}0.075 \\
{[0.069]}\end{array}$ & $\begin{array}{l}0.067 \\
{[0.062]}\end{array}$ & $\begin{array}{l}0.063 \\
{[0.059]}\end{array}$ & $\begin{array}{l}0.060 \\
{[0.057]}\end{array}$ & $\begin{array}{l}0.060 \\
{[0.057]}\end{array}$ & $\begin{array}{l}0.057 \\
{[0.053]}\end{array}$ & \\
\hline 9 & A. raceki & Andoom & $\begin{array}{l}0.137 \\
{[0.119]}\end{array}$ & $\begin{array}{l}0.134 \\
{[0.119]}\end{array}$ & $\begin{array}{l}0.146 \\
{[0.126]}\end{array}$ & $\begin{array}{l}0.139 \\
{[0.121]}\end{array}$ & $\begin{array}{l}0.138 \\
{[0.121]}\end{array}$ & $\begin{array}{l}0.138 \\
{[0.121]}\end{array}$ & $\begin{array}{l}0.139 \\
{[0.121]}\end{array}$ & $\begin{array}{l}0.151 \\
{[0.129]}\end{array}$ \\
\hline
\end{tabular}




\section{Taxonomy}

\section{Gecarcinucidae Rathbun, 1904}

\section{Austrothelphusa Bott, 1969}

Holthuisana (Austrothelphusa) Bott, 1969: 363.

Type species Thelphusa transversa von Martens, 1868, by original designation; gender feminine); Austrothelphusa raised to generic status by Davie (2002: 375, 377).

\section{Austrothelphusa wasselli species-complex}

Diagnosis. Carapace broadly oval, moderately convex; surface medially punctate; gastro-cardiac (H-shaped) grooves present but not strongly marked; epigastric regions separated by median groove; epigastric crests absent or poorly developed; postorbital crests low or absent; branchial regions not markedly swollen, lacking anterolateral striations, punctate; cervical grooves shallow, poorly marked; anterolateral margins smoothly cristate, evenly convex, with one, more or less distinct, but always small epibranchial tooth. Frontal and orbital margins with raised rim. Exorbital angle spine moderately blunt. Posterolateral borders straight, convergent posteriorly, bearing oblique striations. Front more or less bilobed. Male pleon broadly triangular; somites 4 and 5 strongly tapering; somite 6 slightly tapering; telson length subequal to breadth at base, tongue-shaped. Small species, typically less than 25 $\mathrm{mm}$ maximum carapace width; females with mature pleon by $13 \mathrm{~mm} \mathrm{CW}$.

Remarks. Justification for using the term "species-complex" to treat a group of samples from various river catchments from across Cape York, is given elsewhere in this paper, and will not be repeated here. Suffice to say that we have found discrete morphological patterns within the broad geographic range currently ascribed to $A$. wasselli sensu lato, and these differences are supported by significant genetic divergence. It is intended to describe a number of further new species as a result of our ongoing study exploring the phylogeny of this group using both mitochondrial and nuclear genetic markers.

The members of the $A$. wasselli species-complex are easily recognisable from other Austrothelphusa species by: the relatively unswollen anterolateral branchial regions that lack obvious oblique striations; the telson of the male pleon being about as long as wide at base; and the small size when fully grown, especially the small size of females at sexual maturity.

Based on pleon shape, A. wasselli sensu lato is closest to A. raceki (Bishop 1963: fig. 2A). Preliminary unpublished genetic results (P.J.F. Davie \& D. Gopurenko) also indicate that $A$. raceki samples form the sister clade to $A$. wasselli sensu lato.

\section{Austrothelphusa wasselli (Bishop, 1963)}

(Figs 3, 4, 5, 6A-C, 7A, C, E, F)

Parathelphusa wasselli Bishop, 1963: 229-230, figs 1A, 2D, 4, pl. 1, fig. 1.

Material examined. Holotype (AM-P.14524), male $(11.2 \times 9.2 \mathrm{~mm})$, Port Stewart District, Cape York, May-June 1954, J. L. Wassell. QM-W20049, 2 males $(25.8 \times 20.5 \mathrm{~mm}, 16.5 \times 13.1 \mathrm{~mm}$, Stewart River, Queensland, coll. B. Herbert, J. Peeters (QDPI, CYPLUS), 21.04.1993. QM-W29187, male $(18.8 \times 14.9 \mathrm{~mm})$, Oscar Creek, $2.1 \mathrm{~km} \mathrm{SSE}$ of Coen, Archer Catchment, Queensland, coll. K. McDonald, 8.05.2013.

Description. Small species (maximum CW of present material $25.8 \mathrm{~mm}$ ). Carapace broadly oval (Figs. 3A, 4A); 1.26 times broader than long $(\mathrm{n}=3 ; \mathrm{CW}>16.6 \mathrm{~mm})$; small specimens with less swollen branchial regions so typically narrower (holotype 1.21 times broader than long; CW $11.2 \mathrm{~mm}$ ). Front projecting beyond level of exorbital angles, broadly bilobed, medial concavity shallow; inner part of supraorbital margin moderately welldefined, merging quite steeply with lateral slope of frontal lobe (Fig. 7A). Frontal and orbital margins with raised rim. Postfrontal (epigastric) lobes rounded, not well developed, lacking striated crests; separated by deep narrow groove. Postorbital region moderately depressed, short slightly convex crest laterally adjacent to, but not quite reaching, epibranchial tooth. Anterolateral margins smoothly cristate, evenly convex, with one distinct but small 
epibranchial tooth. Branchial regions not swollen, bearing punctations; anteriorly lacking striations but with striated ridges posterolaterally. Cervical groove shallow, relatively poorly defined; gastro-cardiac (H-shaped) grooves not strongly marked. Posterolateral borders straight, convergent posteriorly.
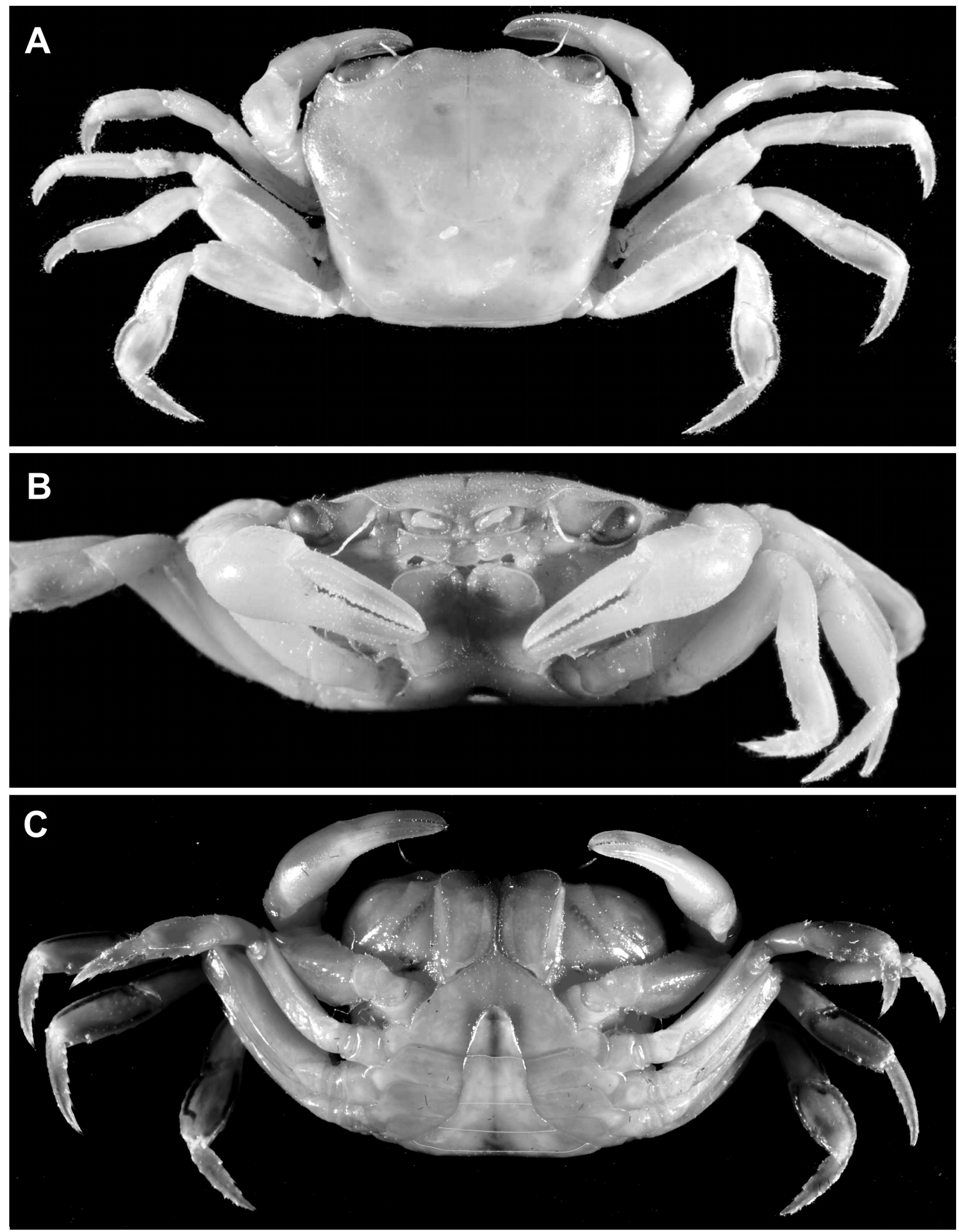

FIGURE 3. Austrothelphusa wasselli, holotype male $(11.2 \times 9.2 \mathrm{~mm})$, Port Stewart District, Cape York (AM-P.14524). A, dorsal view; B, frontal view; C, ventral view. 


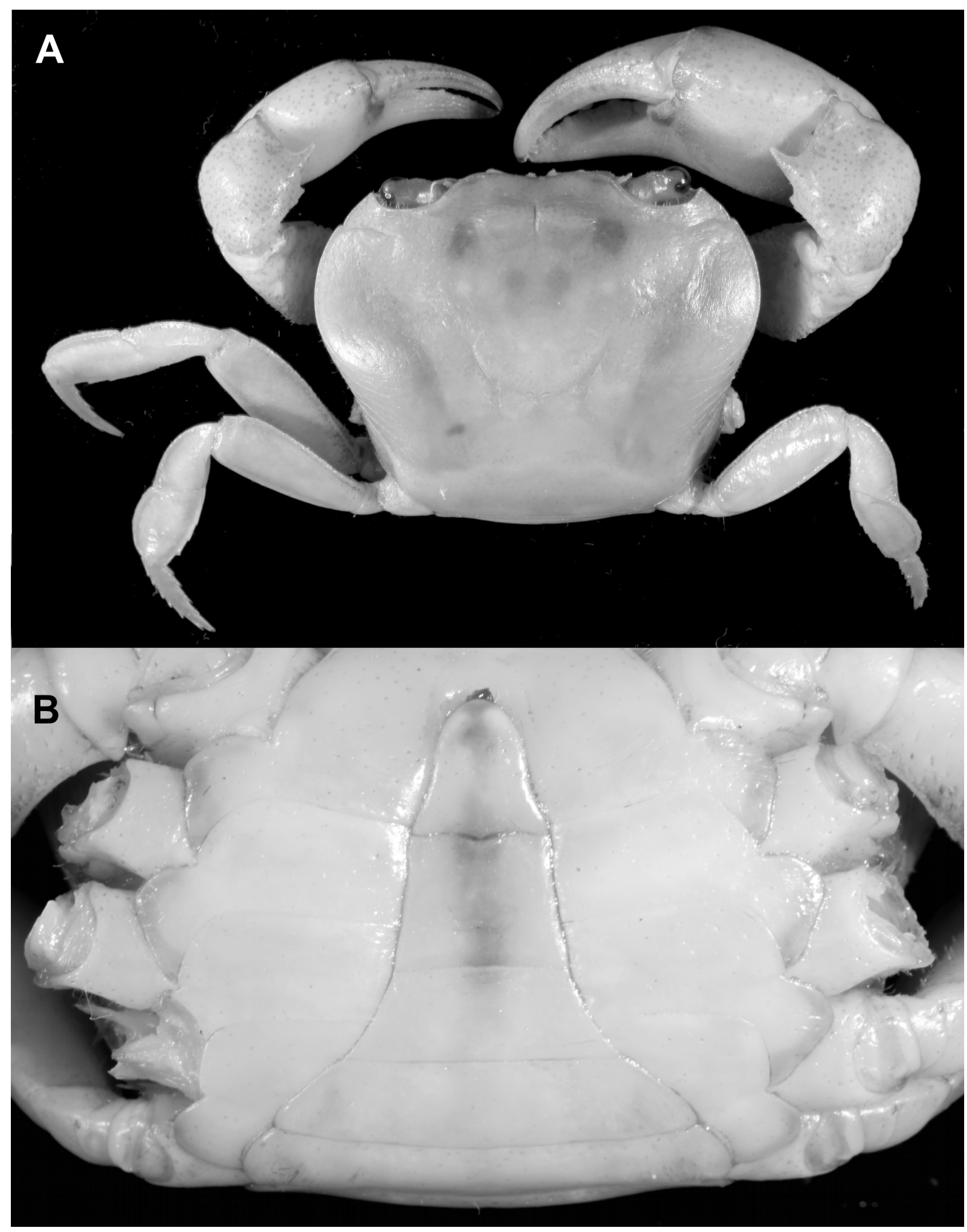

FIGURE 4. Austrothelphusa wasselli, male $(25.8 \times 20.5 \mathrm{~mm})$ Stewart River, Queensland QM-W20049. A, dorsal view; B, ventral view of sternum and pleon.

Male pleon (Figs. 4B, 6C) broadly triangular; telson tapering, apex rounded, length subequal to breadth at base. Somite 6 slightly tapering (proximal width 1.3 times distal width), c. 1.64 times wider at base than long. 
Somite 5 more strongly tapering (proximal width 1.6 times distal width), c. 2.97 times wider at base than long. Somite 4 also strongly tapering (proximal width 1.52 times distal width), c. 4.4 times wider at base than long. Somites 2 and 3 broad, with lateral margins evenly rounded, narrow longitudinally. [The figure given of the pleon of $A$. wasselli by Bishop (1963: fig. 2D) appears to be in error by showing somite 5 to be longer than somite 6 . This is not found in any other species of Austrothelphusa and does not represent the holotype (Fig. 3C) or other topotypic males in the present study.]

Walking legs moderately long, total length of P5 (basis to tip of dactyl) c. 1.1 times maximum carapace width. P5 (Fig. 7C): merus with anterior and posterior borders subparallel, slightly convex, 2.77 times longer than wide; propodus short, anterior border moderately convex, 1.94 longer than wide; dactylus short, similar in length to propodus (1.04 times).

G1 (Fig. 7E, F) short, broad basally but tapering and slender over distal half, moderately curved inward apically. Outer lateral margin (in sternal view) relatively straight (slightly concave) over basal two-thirds, before curving inwards towards apex. Terminal opening very small, V-shaped, apical flanges smoothly tapering. Some sparse long simple setae along inner margin towards tip.

Colour. Preserved material retains a smattering of tiny red dots on the anterolateral regions of the carapace. Live colours not recorded.

Distribution and ecology. Here recorded from the Stewart and adjacent Archer River Catchments, Cape York, Queensland (Fig. 1). Holotype was collected from under leaves on the hard bottom of a temporary freshwater lagoon.
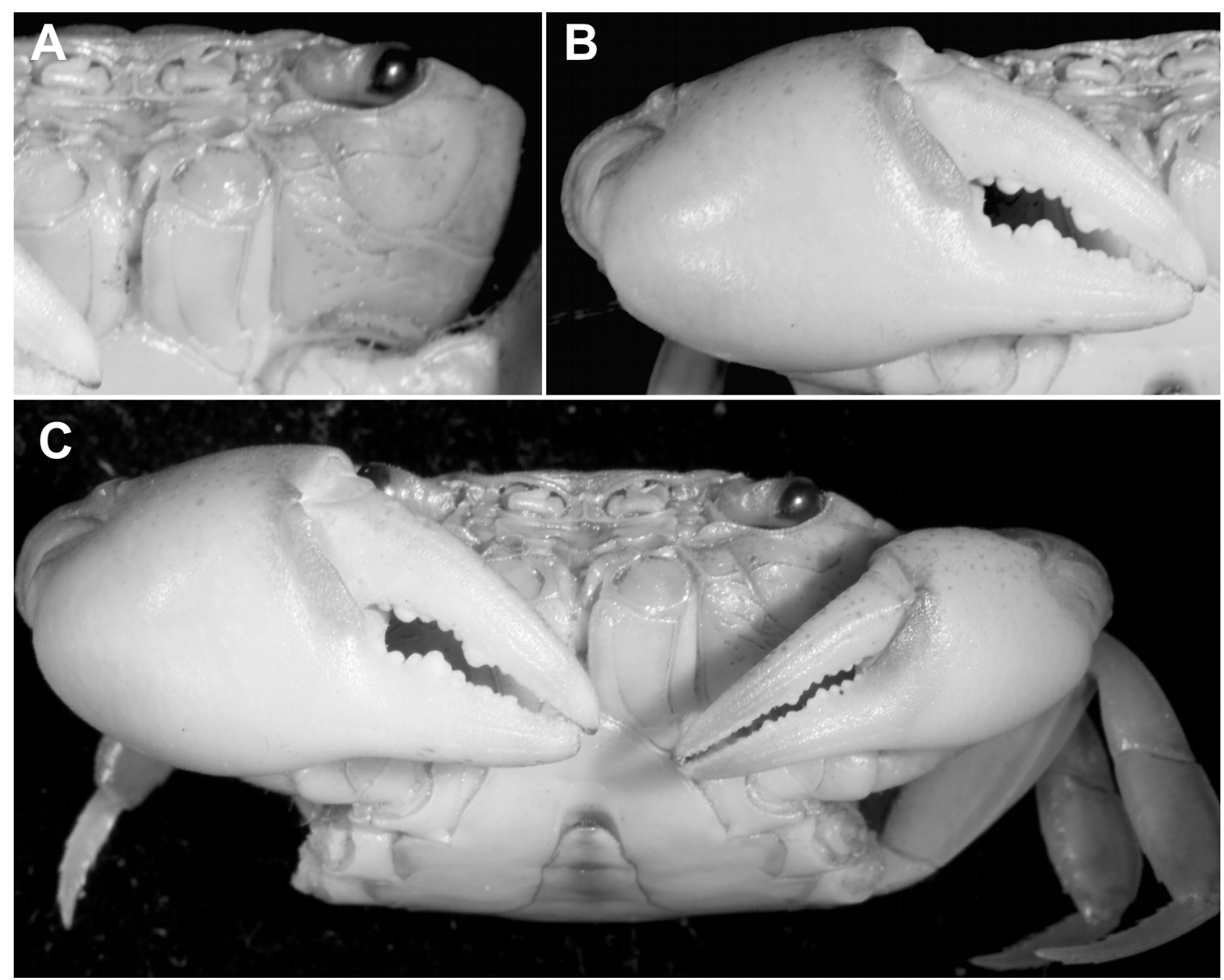

FIGURE 5. Austrothelphusa wasselli, male $(25.8 \times 20.5 \mathrm{~mm})$ Stewart River, Queensland QM-W20049. A, ventrofrontal view; $\mathrm{B}$, outer view of major chela; $\mathrm{C}$, ventrofrontal view showing chelae and third maxillipeds. 
Remarks. Bishop (1963) described A. wasselli based on small specimens collected from the Port Stewart District, Cape York, with carapace widths ranging from 8 to $19 \mathrm{~mm}$. Thus the biggest male we examined here (25.8 $\mathrm{mm} \mathrm{CW}$ ) is considerably larger than the types, but nevertheless it and our other samples agree in all morphological respects with the holotype (Fig. 3). Although not designated as part of the type series, Bishop also identified samples from the Coen River, at Coen as being conspecific. While these two localities represent two separate catchments, the easterly flowing Stewart Catchment, and the westerly flowing Archer Catchment (Fig. 1), we have not found any morphological differences, and the genetic divergence is low $(1.8 \%)$, as is discussed more fully later. We therefore agree that $A$. wasselli does also occur in the Archer Catchment. This seems understandable because the two catchments are separated by only a low and narrow section of the McIlwraith Range to the east of Coen, with the creeks at the headwaters of each catchment being geographically very close.

Riek (1951: 354) reported Paratelphusa (Liotelphusa) planifrons (Bürger, 1894) from the Mitchell Catchment (Walsh River and Mutchilba), but Bishop (1963: 229, 230) considered these samples to be a misidentification, and instead re-identified Riek's samples as his own new species, A. wasselli (Bishop, 1963). However Bishop (as with the Coen River samples), specifically did not include them as part of his type series of $A$. wasselli. As part of a larger study of $A$. wasselli sensu lato, the present authors suspect that the crabs from the Mitchell River Catchment may belong to a discrete species for which the name Austrothelphusa plana (McCulloch, 1917) is likely to be available (Geothelphusa leichardti var. plana McCulloch, 1917, was described from Eureka Creek, Walsh River, within the Mitchell Catchment), and we have thus not included Riek's identification as part of the synonymy for $A$. wasselli.
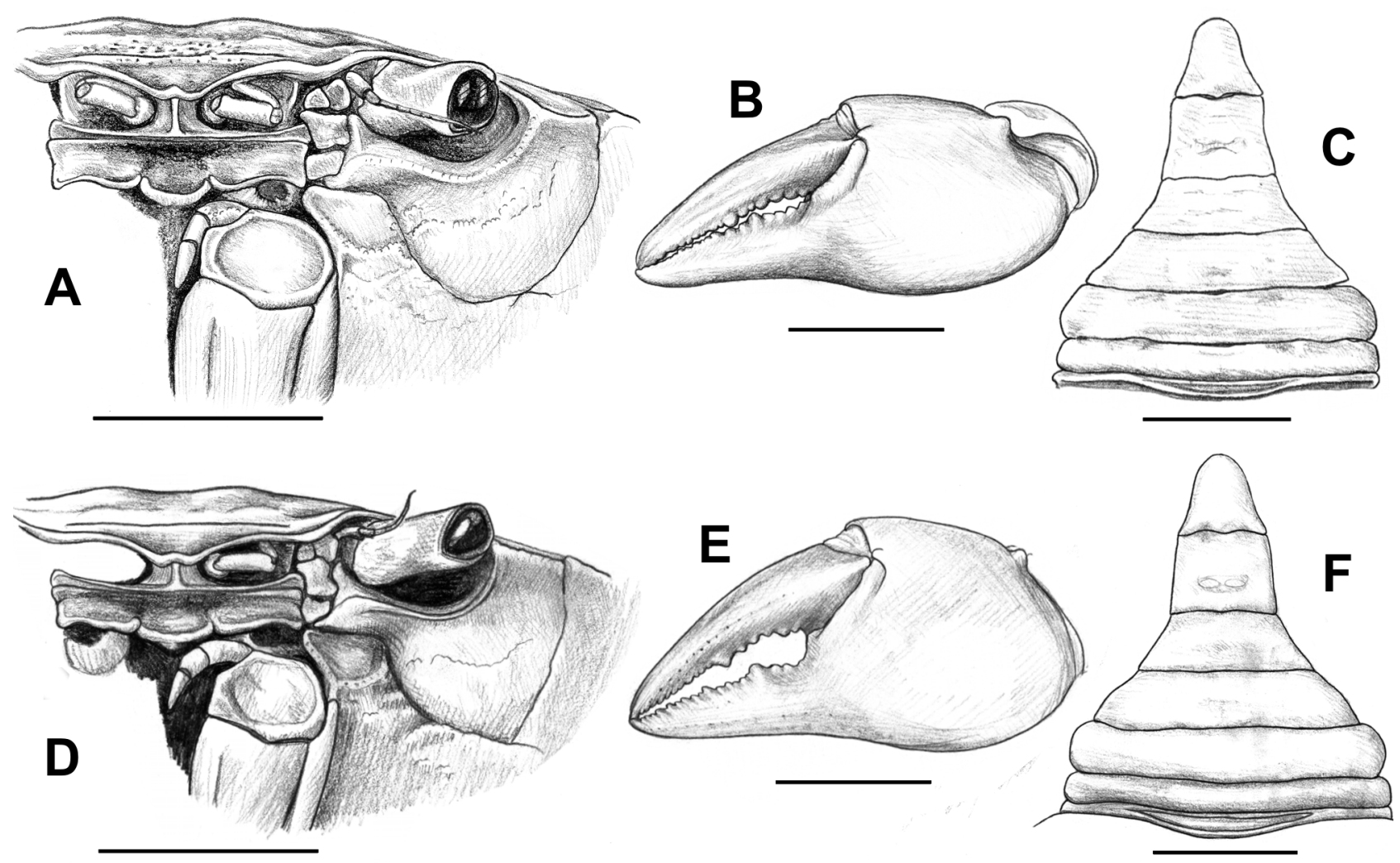

FIGURE 6. A-C, Austrothelphusa wasselli, male $(18.8 \times 14.9 \mathrm{~mm})$, Oscar Creek, $2.1 \mathrm{~km}$ SSE of Coen, Archer Catchment, Queensland (QM-W29187). D-F, A. gilbertensis sp.nov., holotype male $(11.2 \times 9.2 \mathrm{~mm})$, Port Stewart District, Cape York (AM-P.14524). A, D, ventrofrontal view of cephalothorax (orbit, frontal triangle, epistome and pterygostome); B, E, left major chela; C, F, pleon. Scale line $5 \mathrm{~mm}$.

The type locality of "Cape York" for Telphusa planifrons Bürger, 1894, is now considered to have been erroneous, and it seems clear that T. planifrons is generically unrelated to Austrothelphusa (see Bott 1970: 50-51). Bishop (1963) identified six female crabs collected from the Upper Naru River, New Guinea as appearing to agree with Bürger's (1894) description, thus inferring that Telphusa planifrons was most likely a New Guinean species. However, Bott (1970) pointed out that Bürger compared his T. planifrons with specimens he had identified as $T$. 
transversa from Calcutta, but that species is otherwise indigenous to Australia. Thus the most parsimonious explanation is that the labels became mismatched, with the "Indian" T. tranversa coming from Australia, and the "Australian" T. planifrons from Calcutta, India. Bott (1970) somewhat inexplicably placed T. planifrons as a subspecies of Liothelphusa laevis, while otherwise stating in his remarks that its closest relative was L. bakeri (Alcock, 1909) [now in Globithelphusa, see Ng et al. 2008]. The holotype of Telphusa planifrons was originally deposited in the Göttingen Zoological Museum, but is now in the collections of the Senckenberg Museum, Frankfurt (SMF-ZMG699). It will need to be carefully re-examined, but from the description and figures of Bürger (1894) and of Bott (1970, pl. 7, figs 79-81) we agree with Bott (1970) that it cannot belong to Austrothelphusa and it looks most like a Globithelphusa species as indicated by Ng et al. (2008). In particular, "Telphusa" planifrons has a strongly vaulted carapace, with the body much deeper than in Austrothelphusa species; and the front is longer significantly more deflexed, and the lateral margins subparallel, unlike anything seen in Austrothelphusa.

\section{Austrothelphusa gilbertensis sp. nov.}

(Figs 6D-F, 7B, D, G, H, 8-10)

Material Examined. HOLOTYPE: QM-W28346, male $(22.3 \times 17.6 \mathrm{~mm})$, Venture Creek, E of Croydon, Gilbert Catchment, Queensland, J. \& S. Hasenpusch, 01.05.2006. Paratypes: QM-W28040, 3 males $(23.0 \times 18.1,22.9 \times$ $18.1,19.9 \times 15.6 \mathrm{~mm}), 8$ females $(24.3 \times 19.1,24.3 \times 19.1,23.5 \times 18.5,22.6 \times 17.9,22.0 \times 17.2,19.8 \times 15.6,21.4$ $\times 16.8,18.4 \times 14.5 \mathrm{~mm})$, same data as holotype. QM-W28339, male $(20.5 \times 16.1 \mathrm{~mm})$, small creek off Gilbert River, coll. Nathan Waltham, 9.05.2014. QM-W28305, female $(16.0 \times 12.6 \mathrm{~mm})$, Pleasant Creek, off Gilbert River, coll. S. Hedge \& J. Sariman, 03.04.2007.
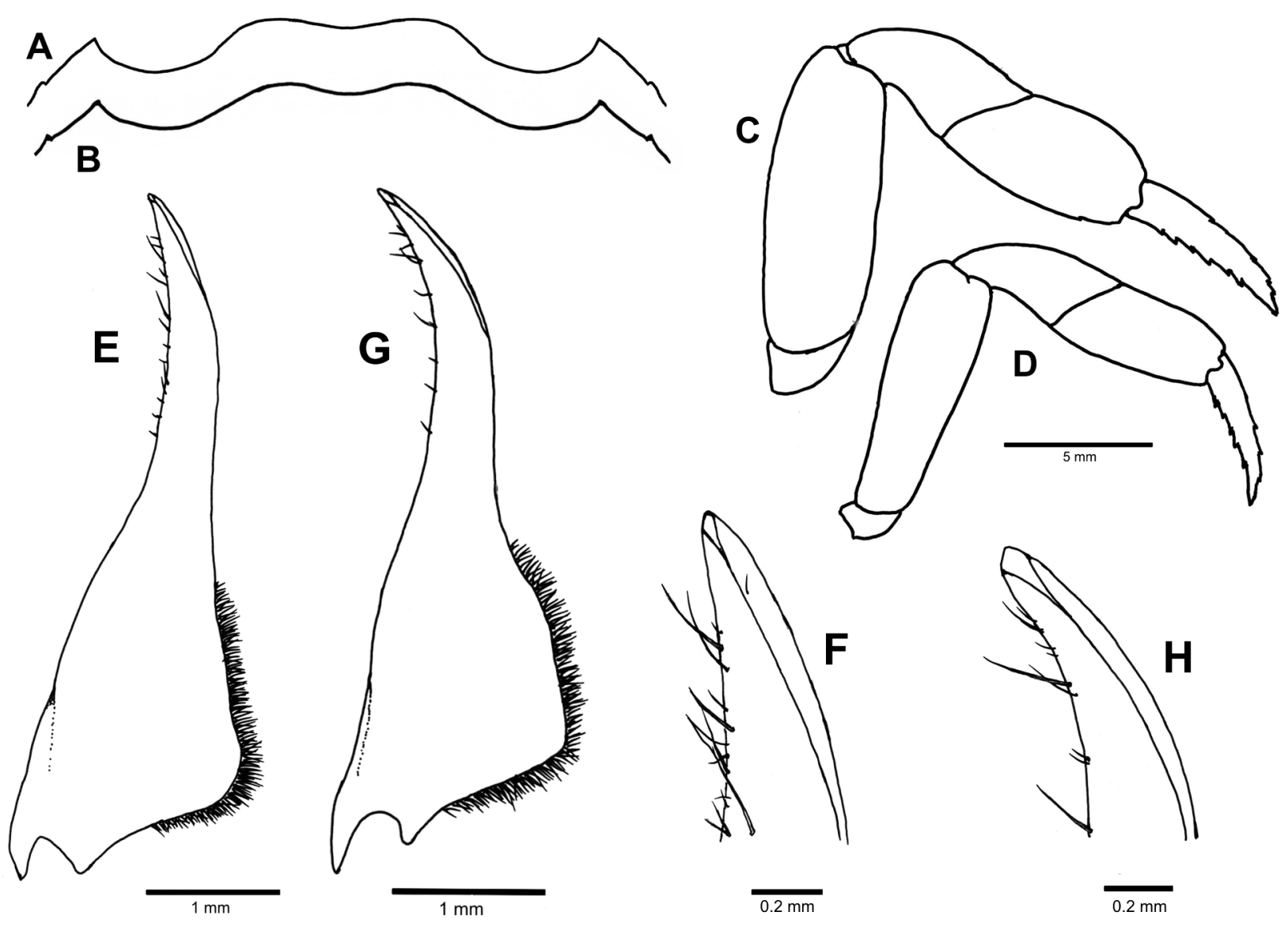

FIGURE 7. A, C, E, F, Austrothelphusa wasselli, male $(25.8 \times 20.5 \mathrm{~mm})$, from Stewart River, Queensland (QM-W20049). B, $\mathrm{D}, \mathrm{G}, \mathrm{H}$, A. gilbertensis sp. nov., holotype male $(22.3 \times 17.6 \mathrm{~mm})$, Venture Creek, E of Croydon, Gilbert Catchment, Queensland (QM-W28040). A, B, outline of frontal margin and orbits; C, D, fifth pereiopod; E-H, left first gonopod (sternal view) with magnification of apical part. 
Description. Small species (maximum $\mathrm{CW}$ of present material, female $24.3 \mathrm{~mm}$ ). Carapace of mature specimens broadly oval (Fig. 8A), c. 1.27 times broader than long (range 1.26-1.28, $\mathrm{n}=14$ ). Front projecting beyond level of exorbital angles, prominently bilobed, medial concavity relatively deep; inner part of orbital cup poorly defined, merging broadly with lateral slope of frontal lobe (Fig. 7B). Frontal and orbital margins with raised rounded rims. Postfrontal (epigastric) lobes moderately well developed, bearing distinct striated ridges; separated by deep narrow groove. Postorbital region moderately depressed, short slightly convex crest laterally adjacent to, but not quite reaching, epibranchial tooth. Anterolateral margins smoothly cristate, evenly convex, distinct but small epibranchial tooth (relatively more prominent than in $A$. wasselli). Branchial regions moderately but not markedly swollen, bearing punctations; anteriorly lacking striations but with striated ridges posterolaterally. Cervical groove shallow, relatively well defined, deeper than in A. wasselli); gastro-cardiac (H-shaped) grooves relatively well defined. Posterolateral borders straight, convergent posteriorly.

Male pleon (Fig. 6F, 8B, 10C) broadly triangular; telson tapering, apically rounded, length subequal to breadth at base. Somite 6 slightly tapering (proximal width 1.26 times distal width), c. 1.38 times wider at base than long; with a pair of slightly raised transverse rounded crests distomedially. Somite 5 more strongly tapering (proximal width 1.54 times distal width), c. 2.75 times wider at base than long. Somite 4 also strongly tapering (proximal width 1.57 times distal width), c. 4.3 times wider at base than long. Somites 2 and 3 broad, with lateral margins evenly rounded, narrow.

Walking legs moderately long, total length of P5 (basis to tip of dactyl) c. 1.1 times maximum carapace width. P5 (Fig. 7D): merus with anterior and posterior borders diverging distally, relatively straight, 3.11 times longer than wide; propodus short, anterior border only weakly convex, 2.07 times longer than wide; dactylus short, slightly longer than propodus (1.12 times).

G1 (Fig. 7G, H) short, broad basally but tapering and slender over distal half, markedly curved inward apically. Outer lateral margin (in sternal view) broadly concave through medial third, before curving inwards towards apex. Terminal opening small, elongate V-shaped, apical flanges smoothly tapering. Some sparse long simple setae along inner margin towards tip.

Colour. Dorsal surfaces of fresh and recently preserved material are grey to yellowish-green; a scattering of well separated, small, but obvious and discrete red dots across the dorsal surfaces of the carapace, walking legs and claws. Ventral surfaces generally pale yellow. Frontal face of chelae pale yellow with an oblique broad band of orange behind the gape; tips of fingers orange (Fig. 10).

Distribution and ecology. Only known from a restricted area in the central region of the Gilbert River Catchment (Fig. 1), but further collecting will presumably find it to be more widespread within the catchment. Found in freshwater pools, and at the edge of small creeks, on clay and firm mud substrates; often under leaves.

Etymology. The species is named for its Gilbert River type locality.

Remarks. As already discussed the COI barcoding region for Austrothelphusa gilbertensis sp. nov. shows it to be genetically distinct from $A$. wasselli by $5.4-6.4 \%$ (also see further comment in the Discussion). Careful examination also shows a number of significant morphological differences that can be used to easily separate the two species:

Austrothelphusa gilbertensis sp. nov. differs from A. wasselli by: 1) having relatively more prominent epibranchial teeth; 2) the front has a relatively deep medial concavity (Fig. 7B), versus much shallower in $A$. wasselli (Fig. 7A); 3) the inner part of the orbital cup is poorly defined, broadly merging with the lateral slope of the frontal lobe (Fig. 7B), whereas in A. wasselli the inner part of the orbital cup is moderately well-defined, merging quite steeply with the lateral slope of the frontal lobe (Fig. 7A); 4) the postfrontal (epigastric) lobes are moderately well developed, bearing distinct striated ridges, versus not well developed, and lacking striated crests in A. wasselli; 5) the cervical groove is relatively well defined, and deeper than in $A$. wasselli; 6 ) the gastro-cardiac (H-shaped) grooves are relatively well defined, versus shallower and less defined in A. wasselli; 7) somite 6 of the male pleon is c. 1.38 times wider at the base than long, versus c. 1.64 times in $A$. wasselli; and bears a pair of slightly raised transverse rounded crests distomedially (Fig. 9C) that are lacking in A. wasselli; 8) somite 5 of the male pleon is c. 2.75 times wider at base than long, versus c. 2.97 times in $A$. wasselli; 9) the merus of P5 has the anterior and posterior borders diverging distally, relatively straight, and 3.11 times longer than wide (Fig. 6D), versus anterior and posterior borders subparallel, slightly convex, and only 2.77 times longer than wide in $A$. wasselli (Fig. 6C); 10) the G1 is markedly curved inward apically, with the outer lateral margin (in sternal view) broadly concave through the medial third (Fig. 7G), versus moderately curved inward apically, and outer lateral 
margin relatively straight over the basal two-thirds in A. wasselli (Fig. 7E); and finally, 11) the live colour patterns differ-A. gilbertensis has obvious small well-spaced dark spots across the anterolateral and medial parts of the carapace (Fig. 10), whereas A. wasselli has more of a speckling of fine small red dots, across the anterolateral half of the carapace.

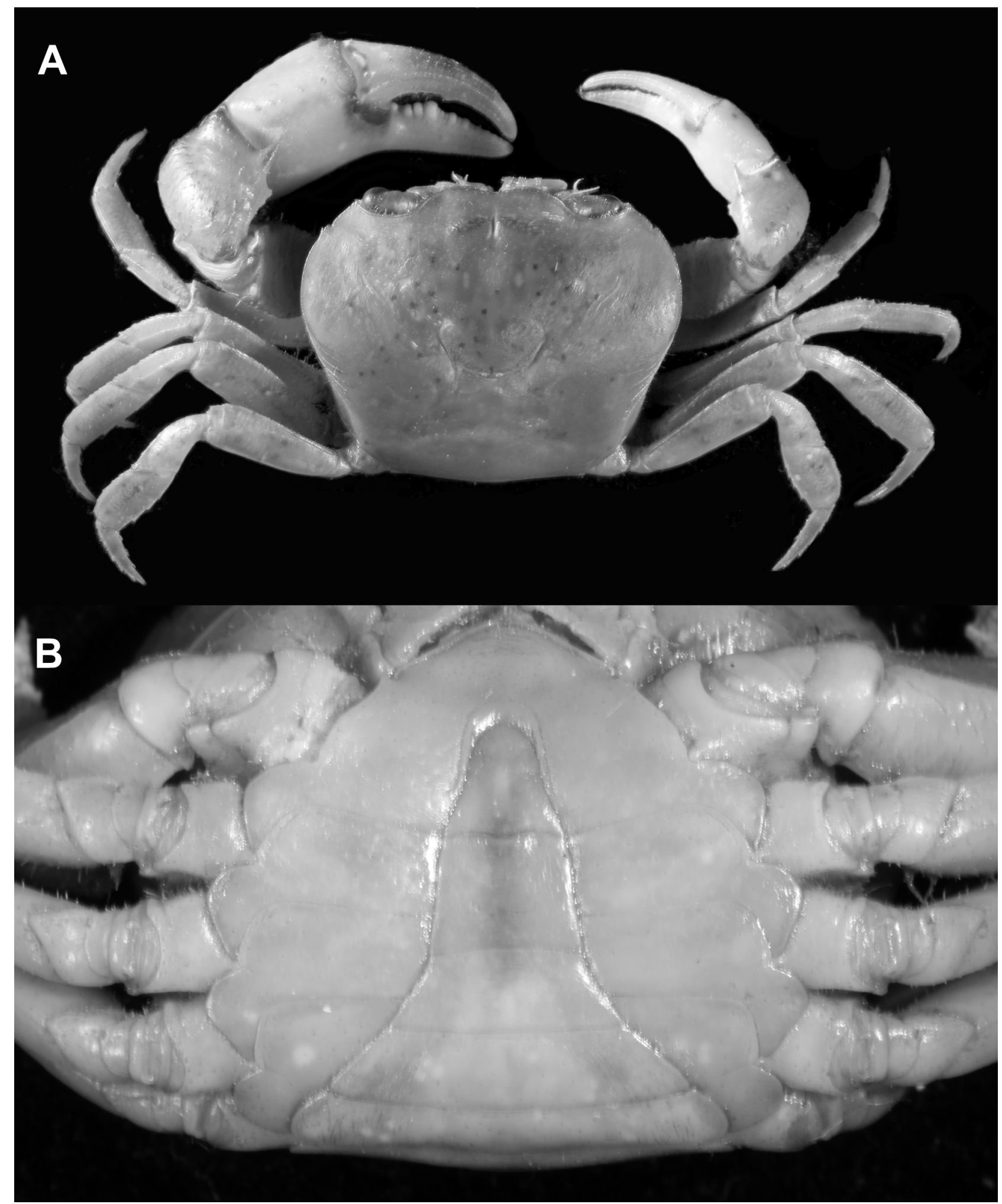

FIGURE 8. Austrothelphusa gilbertensis sp. nov., holotype male $(22.3 \times 17.6 \mathrm{~mm})$. A, dorsal view; B, ventral view of sternum and pleon. 

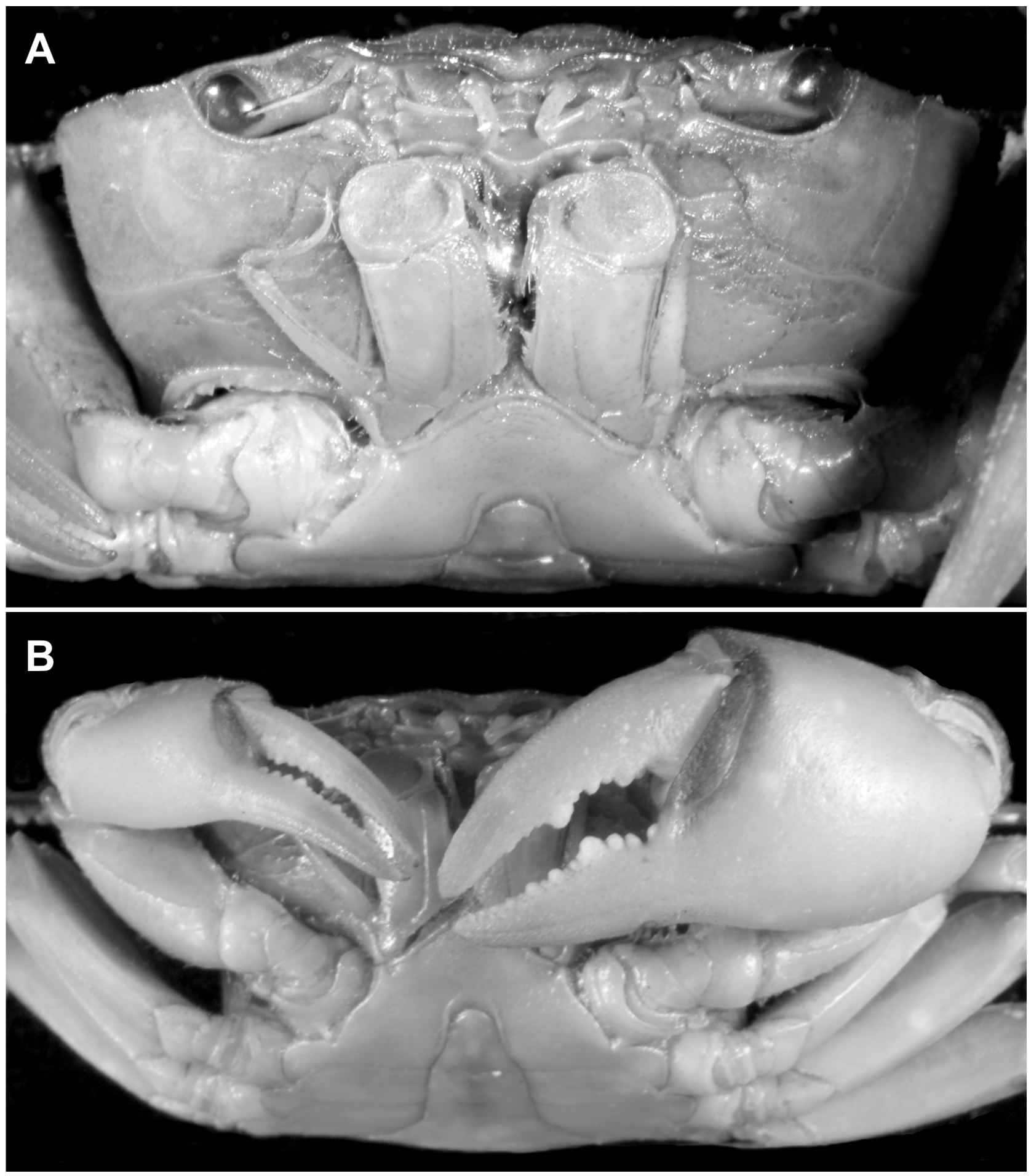

FIGURE 9. Austrothelphusa gilbertensis sp. nov., holotype male $(22.3 \times 17.6 \mathrm{~mm})$. A, ventrofrontal view, showing maxillipeds; B, outer view, showing chelipeds. 

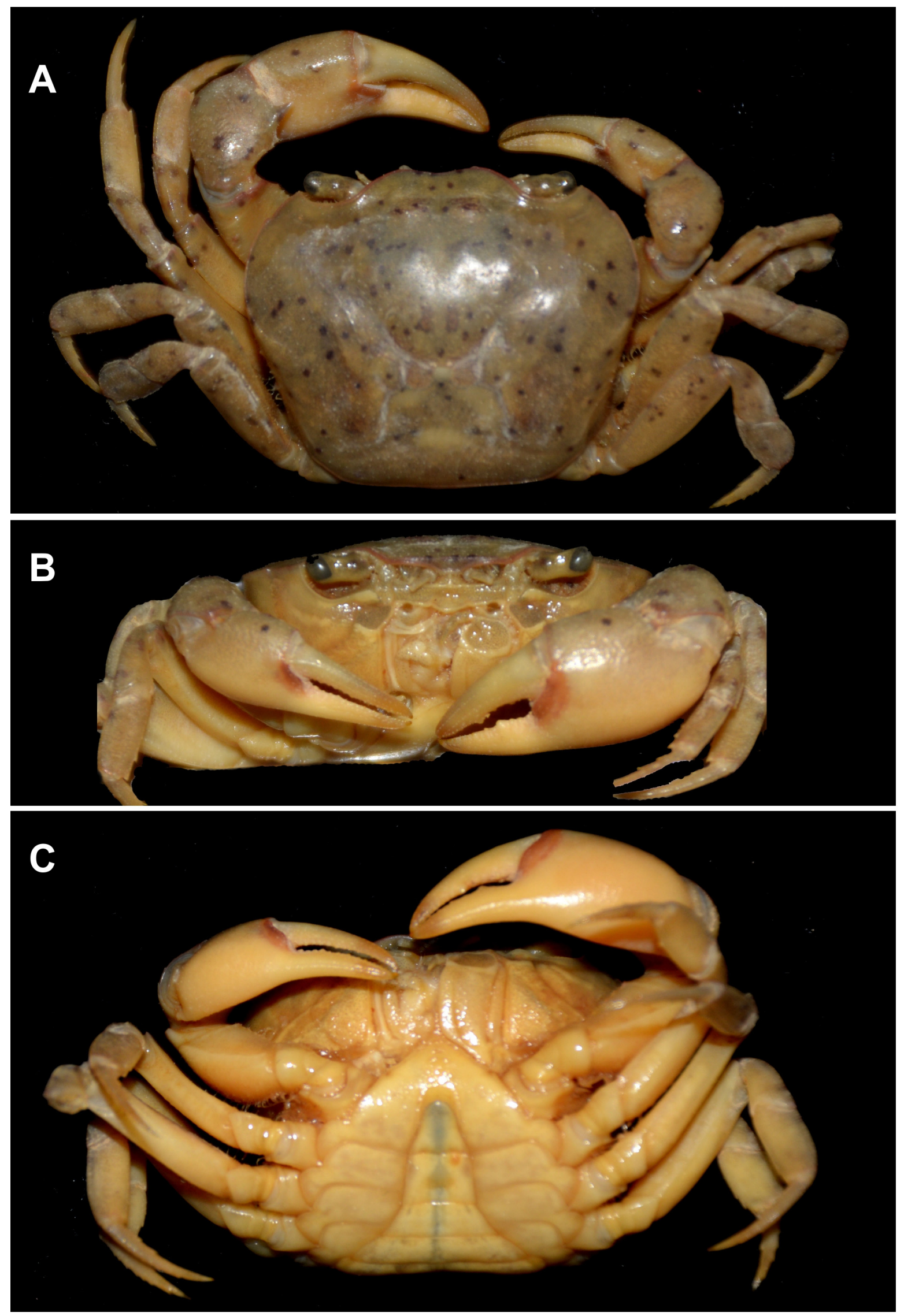

FIGURE 10. Live colouration of Austrothelphusa gilbertensis sp. nov., male $(20.5 \times 16.1 \mathrm{~mm})$, small creek off Gilbert River (QM-W28339). A, dorsal view; B, frontal view; C, ventral view. 


\section{Discussion}

Davie \& Gopurenko (2010) discussed their unpublished genetic work indicating the fact that there are many more species within Austrothelphusa than previously thought. They concluded that there were numerous cryptic species isolated within the many coastal catchments across northern Australia, and that there were several clades potentially signaling different species complexes, and separate species radiations. Based on these earlier results, the present authors have further hypothesised that radiation within species-complexes may be the result of isolation within single river catchments preventing gene flow, and thus leading to the separation of "cryptic" or "pseudocryptic" sister species. To test this hypothesis, we have begun a morphological and genetic study to investigate such possible speciation within museum collections of $A$. wasselli sensu lato, which we here consider to be a species-complex. The present results are the first part of this bigger study, and so far support the broader hypothesis.

Unlike most marine crabs, gecarcinucids do not have a planktonic larval stage, instead having direct development, with young crabs hatching from the large eggs. Typically, adults of Austrothelphusa species can burrow to about one metre in swampy ground or into the banks of rivers, creeks or waterholes (Waltham 2016). They can survive several years of drought by plugging their burrows with clay (Davie 2002). Because these crabs primarily live in lentic ecosystems, the lack of larval dispersal means that they have a very limited capacity to disperse, and this means that catchment boundaries are likely to be effective barriers to movement. Dispersal of adults during periods of monsoonal flood conditions remains a possible scenario, and we here postulate that this has occurred between the adjacent Stewart and Archer Catchments. These two catchments are separated by only a low and narrow section of the Mcllwraith Range to the east of Coen, with the creeks at the headwaters of each catchment being geographically very close.

The phylogenetic tree (Fig. 2) clearly shows the three samples of $A$. gilbertensis sp. nov. form a well-supported monophyletic clade (BI:ML: 1/98) separate to the clade containing A. wasselli samples from the Stewart and Archer Catchments (BI:ML: 1/95). Also based on the COI pairwise K2P distance (Table 2), A. gilbertensis differs from $A$. wasselli samples by $5.4-6.4 \%$, from all other samples by $5-8 \%$, and from the outgroup species, $A$. raceki, by $13-14 \%$. Specimens from Healy Creek (Normanby Catchment) and Howick River (Jeannie Catchment) are separated from each other by at least $6.5 \%$, which is similar to their individual genetic divergences from $A$. wasselli sensu stricto (5-6\%). Each also has supporting morphological differences to separate them, and we expect to describe them as new species in upcoming work as part of the larger study.

The three samples of $A$. gilbertensis sp. nov. show a K2P divergence of as much as $1.8 \%$, despite all three localities being relatively close to each other (Fig. 1), and thus this must be assumed to represent normal intraspecific variation. The samples of $A$. wasselli from the adjacent Stewart and Archer Catchments also show a genetic divergence of only $1.4 \%$. Although not included in the present analysis, another species within the $A$. wasselli complex is being described from the Embley River Catchment, of north-western Cape York (Davie \& Page, in prep.). Genetic analyses on numerous samples throughout this area by Page et al. (2012) found that crabs from the Andoom area in the northern part of the catchment had a COI divergence of $1.9 \%$ from those in the southern Embley, but no morphological differences were discernible. Thus, it seems likely that up to about 2\% COI divergence can be accounted for by intraspecific variation. This is in line with some other studies on marine crabs, e.g., the intertidal soldier crab Mictyris brevidactylus has been found to have up to $1.4 \%$ COI haplotype divergence (Davie et al., 2013). Given the less than $2 \%$ intraspecific divergence so far found, it seems unlikely that further cryptic speciation within catchments, such as identified by Phiri (2014) for Afrotropical freshwater crabs using several different molecular markers, will be detected.

The determination of minimum interspecific distances amongst brachyuran crabs which have closely related species pairs is unpredictable and must be assessed largely on a case-by-case basis. For example, $2 \%$ between Parasesarma samawati Gillikin \& Schubart, 2004, and P. lividum (Milne-Edwards 1869) (Shahdadi et al., 2017); $2.8 \%$ between Neosarmatium africanum Ragionieri, Fratini \& Schubart, 2012, and N. meinerti (De Man, 1887) (Ragionieri et al., 2009; 2012); 1.8\% between Portunus armatus (A. Milne-Edwards, 1861) and P. reticulatum (Herbst, 1799), and 3.5\% between P. segnis (Forskål, 1775) and P. pelagicus (Linnaeus, 1758) (Lai et al., 2010).

Within true freshwater crabs, Shy et al. (2014) quote mean K2P distances varying from $1.48 \%$ to $2.26 \%$ separating closely related Geothelphusa species (Potamidae), e.g., 1.48\%-1.99\% between G. marginata Naruse, Shokita \& Shy, 2004, and G. fulva Naruse, Shokita \& Shy, 2004; 1.65\%-1.98\% distance among G. makatao Shih \& 
Shy, 2009, G. shernshan Chen, Cheng \& Shy, 2005, and G. pingtung Tan \& Liu, 1998; 2.26\% between G. cilan Shy, Shih \& Mao, 2014, and G. monticola Shy, Ng \& Yu, 1994. Similarly, Do et al. (2016) recorded 2.83\% between Geothelphusa candidiensis Bott, 1967, and G. olea Shy, Ng \& Yu, 1994. Based on this comparative evidence, the within-catchment intraspecific variation of up to $1.9 \%$ for the Austrothelphusa wasselli species-complex can be considered relatively high, but the $5-6 \%$ divergences so far found between catchments is very convincing evidence of species separation.

\section{Acknowledgments}

MDN would like to thank the Iraqi Ministry of Higher Education and Scientific Research for awarding the PhD project fund. PJFD is grateful for the past support of a grant from the Australian Biological Resources Study (ABRS) to work on the taxonomy and phylogenetics of Austrothelphusa, and the present paper has arisen out of this research. Peter K.L. Ng provided access to some literature and helped with our understanding of the constitution of Globithelphusa. Finally we would like to thank both Tohru Naruse and a second anonymous reviewer for their careful and useful comments.

\section{Literature cited}

Bishop, J.A. (1963) The Australian freshwater crabs of the family Potamonidae (Crustacea: Decapoda). Australian Journal of Marine and Freshwater Research, 14, 218-238. https://doi.org/10.1071/MF9630218

Bott, R. (1969) Flüsskrabben aus Asien und ihre Klassifikation (Crustacea, Decapoda). Senckenbergiana biologica, 50 (5/6), 359-366.

Bott, R. (1970) Die Süßwasserkrabben von Europa, Asien, Australien und ihre Stammesgeschichte. Eine Revision der Potamoidea und der Parathelphusoidea. (Crustacea, Decapoda). Abhandlungen der Senckenbergischen Naturforschenden Gesellschaft, 526, 1-338.

Bürger, O. (1894) Beiträge zur Kenntnis der Gattung Telphusa. Zoologische Jahrbücher, Abtheilung für Systematik, Geographie und Biologie der Thiere, 8, 1-7, pl. 1.

Burton, T.E. \& Davie, P.J.F. (2007) A revision of the shovel-nosed lobsters of the genus Thenus (Crustacea: Decapoda: Scyllaridae), with descriptions of three new species. Zootaxa, 1429 (1), 1-38. https://doi.org/10.11646/zootaxa.1429.1.1

Colosi, G. (1919) I. Potamonidi conservati nel R. Museo Zoologicao di Firenze. Bolletino Societas Entomologie Italia Firenze, 50 (1918), 39-62.

Costa, F.O., de Waard, J.R., Boutillier, J., Ratnasingham, S., Dooh, R.T., Hajibabaei, M. \& Hebert, P.D. (2007) Biological identifications through DNA barcodes: the case of the Crustacea. Canadian Journal of Fisheries and Aquatic Sciences, 64, 272-295. https://doi.org/10.1139/f07-008

Darriba, D., Taboada, G.L., Doallo, R. \& Posada, D. (2012) jModelTest 2: more models, new heuristics and parallel computing. Nature Methods, 9, 772. https://doi.org/10.1038/nmeth.2109

Davie, P.J.F. (2002) Crustacea: Malacostraca: Eucarida (Part 2: Anomura, Brachyura). In: Wells, A. \& Houston, W.W.K. (Eds.), Zoological Catalogue of Australia. Vol. 19.3b. CSIRO Publishing, Melbourne, pp. 1-641.

Davie, P.J.F. \& Gopurenko, D. (2010) Towards a revision of the Australian Fresh Water Crabs of the genus Austrothelphusa (Brachyura: Parathelphusidae), with a preliminary mitochondrial phylogeny. Abstract of oral paper, 7th International Crustacean Congress, Qingdao, China, July 2010, 16.

Davie, P.J.F., Wisespongpand, P. \& Shih, H.-T. (2013) A new species of Mictyris Latreille, 1806 (Crustacea: Decapoda: Brachyura: Mictyridae) from the Andaman coast of Thailand, with notes on its ecology and behaviour. Zootaxa, 3686 (1), 65-76. https://doi.org/10.11646/zootaxa.3686.1.3

Do, V.T., Shih, H.T. \& Huang, C. (2016) A new species of freshwater crab of the genus Tiwaripotamon Bott, 1970 (Crustacea, Brachyura, Potamidae) from northern Vietnam and southern China. Raffles Bulletin of Zoology, 64, 213-219.

Drummond, A.J., Suchard, M.A., Xie, D. \& Rambaut, A. (2012) Bayesian phylogenetics with BEAUti and the BEAST 1.7. Molecular Biology and Evolution, 29, 1969-1973.

Folmer, O., Black, M., Hoeh, W., Lutz, R. \& Vrijenhoek, R. (1994) DNA primers for amplification of mitochondrial cytochrome c oxidase subunit I from diverse metazoan invertebrates. Molecular Marine Biology and Biotechnology, 3, 294-299. 
Hajibabaei, M., Singer, G.A.C., Hebert, P.D.N. \& Hickey, D.A. (2007) DNA barcoding: how it complements taxonomy, molecular phylogenetics and population genetics. Trends in Genetics, 23, 167-172.

https://doi.org/10.1016/j.tig.2007.02.001

Hebert, P.D.N., Cywinska, A., Ball, S.L. \& de Waard, J.R. (2003) Biological identifications through DNA barcodes. Proceedings of the Royal Society B, 270, 313-322. https://doi.org/10.1098/rspb.2002.2218

Kearse, M., Moir, R., Wilson, A., Stones-Havas, S., Cheung, M., Sturrock, S., Buxton, S., Cooper, A., Markowitz, S., Thierer, C.D.T., Ashton, B., Meintjes, P. \& Drummond, A. (2012) Geneious Basic: an integrated and extendable desktop software platform for the organization and analysis of sequence data. Bioinformatics 28, 1647-1649. https://doi.org/10.1093/bioinformatics/bts 199

Keenan, C.P., Davie, P.J.F. \& Mann, D.L. (1998) A revision of the genus Scylla De Haan, 1833 (Crustacea: Decapoda: Brachyura: Portunidae). Raffles Bulletin of Zoology, 46 (1), 1-29.

Kimura, M. (1980) A simple method for estimating evolutionary rate of base substitutions through comparative studies of nucleotide sequences. Journal of Molecular Evolution, 16, 111-120. https://doi.org/10.1007/BF01731581

Kumar, S., Stecher, G. \& Tamura, K. (2016) MEGA7: Molecular Evolutionary Genetics Analysis version 7.0 for bigger datasets. Molecular Biology and Evolution, 33 (7), 1870-1874. https://doi.org/10.1093/molbev/msw054

Lai, J.C., Ng, P.K.L. \& Davie, P.J.F. (2010) A revision of the Portunus pelagicus (Linnaeus, 1758) species complex (Crustacea: Brachyura: Portunidae), with the recognition of four species. Raffles Bulletin of Zoology, 58, 199-237.

Lefébure, T., Douady, C.J., Gouy, M. \& Gibert, J. (2006) Relationship between morphological taxonomy and molecular divergence within Crustacea: proposal of a molecular threshold to help species delimitation. Molecular Phylogenetics and Evolution, 40, 435-447. https://doi.org/10.1016/j.ympev.2006.03.014

Matzen da Silva, J., Creer, S., dos Santos, A., Costa, A.C., Cunha, M.R. \& Costa, F.O. (2011) Systematic and evolutionary insights derived from mtDNA COI Barcode Diversity in the Decapoda (Crustacea: Malacostraca). PLoS ONE, 6 (5), 1-15, e19449. https://doi.org/10.1371/journal.pone.0019449

Milne-Edwards, A. (1869) Revision du genre Thelphusa. Nouvelles Archives du Muséum d'Histoire naturelle, Paris, 5, 161191.

Ng, P.K.L., Guinot, D. \& Davie, P.J.F. (2008) Systema Brachyurorum: Part I. An annotated checklist of extant brachyuran crabs of the world. Raffles Bulletin of Zoology, 17 (Supplement), 1-296.

Page, T.J., Real, K. \& Hughes, J.M. (2012) A Report to Rio Tinto Alcan regarding the genetic relationships of a new species of freshwater crab (Austrothelphusa sp.) recently reported from the Weipa Area. Australian Rivers Institute, Griffith University, Queensland. [unkown pagination]

Phiri, E.E. (2014) Molecular phylogeny and biogeography of the Afrotropical freshwater crab fauna. PhD Thesis, Stellenbosch University, Stellenbosch, $201 \mathrm{pp}$.

Ragionieri, L., Fratini, S., Vannini, M. \& Schubart, C.D. (2009) Phylogenetic and morphometric differentiation reveal geographic radiation and pseudo-cryptic speciation in a mangrove crab from the Indo-West Pacific. Molecular Phylogenetics and Evolution, 52 (3), 825-834. https://doi.org/10.1016/j.ympev.2009.04.008

Ragionieri, L., Fratini, S. \& Schubart, C.D. (2012) Revision of the Neosarmatium meinerti species complex (Decapoda: Brachyura: Sesarmidae), with descriptions of three pseudocryptic Indo-West Pacific species. Raffles Bulletin of Zoology, $60,71-87$.

Rambaut, A., Suchard, M.A., Xie, D. \& Drummond, A.J. (2014) Tracer v1.6. Available from: http://beast.bio.ed.ac.uk/Tracer (accessed 5 December 2017)

Riek, E.F. (1951) The Australian freshwater crabs (Potamonidae). Records of the Australian Museum, 22, $358-367$.

Ronquist, F., Teslenko, M., Van der Mark, P., Ayres, D.L., Darling, A., Höhna, S., Larget, B., Liu, L., Suchard, M.A. \& Huelsenbeck, J.P. (2012) MrBayes 3.2: efficient Bayesian phylogenetic inference and model choice across a large model space. Systematic Biology, 61, 539-542. https://doi.org/10.1093/sysbio/sys029

Schubart, C.D. \& Huber, M.G.J. (2006) Genetic comparisons of German populations of the stone crayfish, Austropotamobius torrentium (Crustacea: Astacidae). Bulletin Français de la Pêche et de la Pisciculture, 380-381, 1019-1028.

Shahdadi, A., Davie, P.J.F. \& Schubart, C.D. (2017) A new cryptic species of the genus Perisesarma (Decapoda: Brachyura: Sesarmidae) from northern Australian mangroves. [submitted]

Shy, J.Y., Shih, H.T. \& Mao, J.J. (2014) Description of a new montane freshwater crab (Crustacea: Potamidae: Geothelphusa) from northern Taiwan. Zootaxa, 3869 (5), 565-572. https://doi.org/10.11646/zootaxa.3869.5.6

Song, H., Buhay, J.E., Whiting, M.F. \& Crandall, K.A. (2008) Many species in one: DNA barcoding overestimates the number of species when nuclear mitochondrial pseudogenes are coamplified. PNAS, 105, 13486-13491. https://10.1073/pnas.0803076105 
Srivathsana, A. \& Meier, R. (2012) On the inappropriate use of Kimura-2-parameter (K2P) divergences in the DNA-barcoding literature. Cladistics, 28, 190-194.

https://doi.org/10.1111/j.1096-0031.2011.00370.x

Waltham, N.J. (2016) Unravelling life history of the Inland Freshwater Crab Austrothelphusa transversa in seasonal tropical river catchments. Australian Zoology, 38 (2), 217-222.

https://doi.org/10.7882/AZ.2016.034 